DOI: 10.11567/met.28.3.4

Selma Porobić

\section{Resilience and Religion in a Forced Migration Context: A Narrative Study of Religiousness as a Resilience Factor in Dealing with Refugee Experiences from a Post-migration Perspective of Bosnian Refugees in Sweden}

Lund: Lund University, Centre for Theology and Religious Studies, 2011, 394 str.

Knjiga Selme Porobić njena je doktorska disertacija koju je obranila na Sveučilištu u Lundu u Švedskoj. Autorica je bila zaposlena u Centru za teologiju i religijske studije pri tom Sveučilištu, a od 2011. direktorica je Centra za studije o izbjeglim i raseljenim osobama koji je otvoren uz podršku UNHCR-a pri Fakultetu političkih nauka u Sarajevu. Centar je posvećen razumijevanju uzroka i posljedica prisilnih migracija, kao i informiranju i senzibiliziranju javnosti za problematiku izbjeglih i interno raseljenih osoba, što se planira ostvarivati putem istraživačke djelatnosti, edukacija, treninga i javnih rasprava, studentskih programa razmjene i izdavačke djelatnosti. Zasigurno je zanimljiv i značajan kao mjesto buduće suradnje za sve one koji se u široj regiji bave pitanjima istraživanja fenomena raseljenosti i izbjeglištva, kao i evidentiranjem ratnih žrtava, međuetničkim odnosima te procesima pomirbe, tolerancije i razvoja lokalnih zajednica.

Tema disertacije logičan je nastavak autoričinih istraživačkih interesa i aktivnosti nakon dva završena magisterija iz interdisciplinarnog polja na razmeđu psihologije, studija prisilnih migracija i religijskih studija o životu bosanskih izbjeglica u Švedskoj kao i tibetanskih izbjeglica u Sjevernoj Indiji, među kojima je provela terenska istraživanja. Životno iskustvo autorice, koja u Švedsku dolazi 1993. kao izbjeglica te prolazi različite faze ratom potaknute raseljenosti, egzila i (poslije) ratne reintegracije, pretkontekst je iz kojega izvodi motivaciju za disertaciju i nalazi svoj istraživački poticaj, povezujući osobno $\mathrm{s}$ istraživačkim te $\mathrm{s}$ iskustvima svoga humanitarnog rada među izbjeglicama.

U knjizi se analizira kako religija pomaže u nošenju s izbjegličkim iskustvima, pri čemu je naglasak na religioznim i duhovnim mehanizmima pozitivne prilagodbe na traume izbjeglištva. Istraživanje kao primarni izvor podataka uzima narative, tj. životne priče (life-histories) ispitanika sakupljene kroz intervjue, pisane memoare, osobne dnevnike i svjedočanstva raseljenih bosanskih izbjeglica nastanjenih u Švedskoj. Metodologijom primjerenom kvalitativnim istraživanjima $\mathrm{u}$ analizi je primijenjena kombinacija pristupa utemeljene teorije i narativne studije, tj. analize narativa osobnih povijesti. Iako su u pilotistraživanju sudjelovale 352 izbjeglice, u konačnom ih je uzorku bilo dvadeset, jedanaest muškaraca i devet žena koje je iskustvo trauma rata osnažilo u duhovnom smislu. Njihove naracije, izložene iz današnje postmigracijske perspektive, tematiziraju načine na koje su se nosili sa stresnim aspektima rata, izbjeglištva i iskustava reintegracije u društvu zemlje primitka koja im je pružila zaštitu. Svi su ispitanici/ ice ostvarili u Švedskoj pravo na boravak i državljanski status te danas ne izražavaju izrazitu želju za povratkom u $\mathrm{BiH}$.

Knjiga sadržava pet dijelova, predgovor, pogovor i dodatke. U predgovoru se naglašavaju osobna $i$ istraživačka pozadina koje su utjecale na odabir teme i metodologiju istraživanja. U prvome dijelu autorica nas uvodi u predmet istraživanja, 
primijenjenu metodologiju i teorijska polazišta te definira osnovne pojmove koji se upotrebljavaju u knjizi. Donosi i sustavan popis literature koji sadržava sociološke i antropološke radove iz područja prisilnih migracija, »studija traume« i mentalnog zdravlja među izbjegličkim populacijama u svijetu. U drugome su dijelu knjige empirijski podaci o iskustvima ispitanika o životu prije, za vrijeme i nakon rata. Iz fenomenološke perspektive najprije se opisuje sociokulturni i religijski identitet ispitanika, kao i situacijski kontekst prije i za vrijeme rata, a na kraju se analizira postraseljeničko iskustvo, tj. njihov život u Švedskoj. U trećem se dijelu analiziraju narativi ispitanika o resursima kojima ublažavaju patnju i stres zbog iskustva rata $\mathrm{i}$ egzila te o procesima pozitivne prilagodbe i religije kao dijela ponovnog stvaranja osobnoga životnog smisla iz tog iskustva. Predzadnji i zadnji dio knjige donose raspravu i sintezu cjelokupnog istraživanja te diskusiju o tome kamo pozicionirati završne rezultate istraživanja u polju studija religije i studija prisilnih migracija. U dodatku su pozivno pismo i protokol intervjua, sociodemografski podaci o ispitanicima, dodatne informacije o društveno-političkom kontekstu prije i nakon zbjega/preseljenja, osnovni biografski podaci s anonimizacijom stvarnih identiteta ispitanika/ica te isječci iz transkribiranih intervjua iz kojih se vide tehnike analize podataka.

Prema rezultatima istraživanja, među istraživanom je populacijom religijska otpornost i pokretač i dovršetak procesa nadvladavanja traume $\mathrm{u}$ postraseljeničkom razdoblju. Religioznost tako postaje važan osobni čimbenik pozitivnih promjena i aktivnih strategija suočavanja s problemima izbjeglišttva. Umjesto na vrlo često kategoriziranje izbjeglica kroz diskurs »humanitarijanizma« kao pasivnih žrtava ratova i egzila, ova se studija usredotočuje na pitanja otpornosti, snage, izdržljivosti, prilagodbe i fleksibilnosti (resilience) u načinima aktivnoga nošenja s nedaćama (poslije)ratnog iskustva i njihova prevladavanja. Religija je pomogla (re)integraciji bosanskih izbjeglica u švedsko društvo, koje jest receptivno, ali strukturalna diskriminacija na nekim razinama svejedno postoji. U prijeratnome razdoblju među ispitanicima je bila prisutna svojevrsna amalgamacija vjerskoga, nacionalnog i sociokulturnog identiteta u lokalnim razmjerima, kao i na državnoj razini. Povezanost religije i etnonacionalnoga identiteta nije bila toliko jaka, tj. toliko značajna u njihovim predratnim godinama u Bosni da bi utjecala na njihov svjetonazor. $\mathrm{U}$ uzorku je bilo jedanaest muslimana, četiri pravoslavca, dva katolika te troje ispitanika iz miješanog braka, koji su se prije rata uglavnom deklarirali »Bosancima«, a nakon rata imenima svoje etnonacionalne grupe. Budući da se šesnaest od dvadeset ispitanika prije rata deklariralo ateistima, zanimljiv je istraživački rezultat povećanje individualne religioznosti i duhovnosti: danas ih se šesnaest izjašnjava religioznima, a četvero pristašama duhovnosti. Iako su se prije rata smatrali uključenima u pojedine kulturno-tradicijske aspekte religioznosti (npr. proslave blagdana s rodbinom i »komšijama«), ipak su znatno jače odrednice njihova identiteta bile profesijska, regionalna ili lokalna, društvena i/ili (sup)kulturna.

Autorica naglašava da se kod ispitanika najvažnija transformacija uvjetovana ratnim i raseljeničkim iskustvom dogodila u pogledu na sebe i druge, na život, društvo i svijet u cjelini. Ovdje se zapravo implicira (re)sakralizacija svjetovnoga, ali ponajprije na razini individualnoga, a ne 
nužno kolektivnoga vjerskog života. Religioznost je $\mathrm{u}$ ispitanika evocirana kroz produhovljeno poimanje stvarnosti i religiozna tumačenja njihovih osobnih narativa od rata pa do raseljenosti i sadašnje životne poslijeratne situacije. Osobna interpretacija vjere upućuje na stupnjeve »nove produhovljenosti« neovisno o dotadašnjoj tradicionalnoj nacionalnoj i konfesionalnoj pripadnosti ispitanika. No one vrijednosti koje su ostale nepromijenjene iz konteksta iskustava socijalizacije u Jugoslaviji i predratnoj Bosni, bilo kolektivne (multikulturni suživot, tolerancija na razlike, življeni pluralizam), bilo osobne (važnost obitelji i društvenih veza, zdravlja i rada), ispitanici sada sagledavaju kroz novu prizmu duhovnosti i religije, koje su postale središnji dio njihova identiteta (str. 262).

Vrijednost je ovog rada u autoričinu pristupu istraživanju fenomena prevladavanja traume kroz iskustva religioznosti i duhovnosti koji nije dogmatske, nego više situacijske naravi, s utilitarističkim predznakom. Pritom tekst nije esencijaliziranje izbjegličkih i religijski povezanih iskustava, nego analiza fluktuacije u procesima mijenjanja stavova, $i$ to više njihove osobne kognitivne i emocionalne sastavnice nego one konativne izražene kroz kolektivne religiozne prakse. Autorica uspješno izbjegava diskurse koji bi i nehotice vodili stigmatizaciji i reviktimizaciji ispitanika, kao i patologizaciji i medikalizaciji njihovih individualnih iskustava. S druge strane, ne podliježe umjetnoj homogenizaciji i monolitizaciji uzorka ispitanika te reduciranju kulturnih, etničkih i socioekonomskih pozadina kao predtemelja osobnih religijskih i postmigracijskih iskustava. $U$ istraživanju prisilnih migracija na prvo mjesto stavlja iskustva ispitanika kao društvenih aktera koji su ponajprije sami sposobni i odgovorni za suočavanje s negativnim posljedicama rata i raseljenosti u procesu (re)integracije u švedsko društvo i transformaciju tih posljedica.

Svi istraživački postupci valjano su metodološki opravdani. Autorica je upotrijebila triangulacijsku metodu analize transkripata osobnih intervjua, ali i sekundarnih izvora, komplementiranu s participirajućim (kolaborativnim) pristupom u kojemu su ispitanici bili upoznati s cijelim procesom prikupljanja, analize podataka i sinteze završnih rezultata i gdje su u nekim fazama mogli svojim komentarima usmjeriti istraživanje. S druge strane, radne verzije teksta ostavila je dostupnima svojim kolegama i profesorima za komentare i kritike, što je za mlade istraživače validan i hrabar potez. Iako su za ovakvu vrstu rada na terenu, barem u etnografskim studijama, karakteristični autorefleksivno samopozicioniranje i osobni utjecaj autora (pogotovo s obzirom na bliskost teme i ispitanika, kao i slično životno iskustvo), autorica je svoju insajdersku poziciju žrtvovala u korist usmjerenosti na narative ispitanika, zadržavajući samokritičnost i distancu od iznošenja svoga iskustva povezanoga s temom ili stava prema religiji i otpornosti na nedaće, što je, dakako, legitimna pozicija.

U radu je najveći naglasak na psihološkim analizama individualnog iskustva, a manje se tematiziraju kulturni, politički ili društveni aspekti izbjegličkog iskustva. No ova će knjiga naći svoju publiku u širemu krugu društvenih i humanističkih znanstvenika, stručnjaka, medicinskih i socijalnih radnika, teologa i duhovnika kao i svih ostalih zainteresiranih za produbljivanje razumijevanja iskustava izbjeglištva te uloge i potencijala religioznosti u prevladavanju izbjegličkih trauma i održavanju mentalnoga zdravlja. Va- 
lja se nadati prijevodu knjige na bosanski jezik, što bi bilo temelj autoričinih daljnjih istraživanja, možda i u okružju bosanskohercegovačkog društva, o primjerice iskustvima izbjeglica povratnika i na- činima prevladavanja traume, ili transnacionalnim praksama bosanskih izbjeglica koje ih povezuju s prostorima koje su napustili i kamo se (ne) vraćaju.

\section{Drago Župarić-Iljić}

Institut za migracije i narodnosti, Zagreb
DOI: 10.11567/met.28.3.5 Jasna Čapo i Valentina Gulin Zrnić (ur.)

\section{Mjesto, nemjesto. Interdisciplinarna promišljanja prostora i kulture}

\begin{abstract}
Zagreb - Ljubljana: Institut za etnologiju i folkloristiku - Inštitut za antropološke in prostorske študije - Znanstvenoraziskovalni center Slovenske akademije znanosti in umetnosti, 2011, 441 str.
\end{abstract}

Zbornik objedinjuje radove izložene na konferenciji »Od mjesta do nemjesta: interdisciplinarna promišljanja prostora i kulture« koja se 24. i 25. rujna 2009. održala u Institutu za etnologiju i folkloristiku u Zagrebu. Uz opširno uvodno poglavlje urednica zbornik sadržava dvadeset radova na hrvatskome i engleskome podijeljenih na sedam tematskih cjelina. Jasna Čapo i Valentina Gulin Zrnić u uvodnom poglavlju »Oprostornjavanje antropološkog diskursa. Od metodološkog problema do epistemološkog zaokreta« nastoje obuhvatiti »kretanja, smjerove, rubove, granice i graničnosti, mozaike i tokove u odnosu kulture i prostora unutar kulturne antropologije i srodnih disciplina i pristupa" (str. 13). Autorice daju pregled relevantnih koncepata i predstavljaju radove u zborniku smještajući ih u okvir pojedinih pristupa prostoru, mjestu i kulturi. Odnos kulture i prostora tematizira se kroz nekoliko dimenzija (od klasičnih poimanja prosto- ra kao kontejnera kulture do suvremenih koncepata koji naglašavaju njihov procesni i relacijski karakter), a rad ispunjava očekivanja autorica, tj. uistinu je »korisni putokaz u kretanju ovim specifičnim akademskim prostorom « (str. 13).

Prvi dio zbornika Disciplinarne prizme, znanstvene lokacije i nova značenja sadržava četiri rada. »Prostor i mjesto u hrvatskoj etnologiji/kulturnoj antropologiji« Valentine Gulin Zrnić pregled je relevantnih etnoloških i etnografskih radova kroz nekoliko tematskih cjelina, od klasičnih razmatranja izomorfnosti kulture i fizičkog prostora u Radićevim i Gavazzijevim radovima preko konceptualnih pomaka u pristupu prostoru u istraživanjima arhitekture, graditeljstva i stanovanja $\mathrm{s}$ jedne i primjerice turizma i ekologije $\mathrm{s}$ druge strane, do radova koji tematiziraju »transnacionalne društvene prostore«, virtualne prostore i druge koncepte koji ne pretpostavljaju istovjetnost zajednica i lokalitetâ. U svome radu Laura Šakaja razmatra »Mjesto u diskursu humane geografije« od njegova lokacijskog aspekta, preko fenomenološke koncepcije »osjećaja mjesta«, koncepta »trećeg prostora i odnosa mjesta s prostorom i teritorijem, obuhvaćajući utjecajne koncepcije i njihovu kritiku. U ovome dijelu nalaze se još i radovi Sarah Czerny i Melanije Belaj, koji su, poput priloga koji slijede u zborniku, etnografske studije, u ovom sluča- 